\title{
SCANNING ELECTRON MICROSCOPY OF RABBIT AND MONKEY FEMALE REPRODUCTIVE TRACT EPITHELIUM
}

\author{
E. S. E. HAFEZ \\ Departments of Gynecology-Obstetrics and Physiology, \\ Wayne State University School of Medicine, Detroit, Michigan, U.S.A.
}

(Received 7th Fanuary 1972, accepted 1st February 1972)

Scanning electron microscopy (SEM) has been used to study the morphology of mammalian spermatozoa (Dott, 1969; Fujita, Miyoshi \& Tokunaga, 1970; Luse, 1970; Zaneveld, Gould, Humphreys \& Williams, 1971), ova (Gould, Zaneveld, Humphreys \& Williams, 1971) and cilia (Barber \& Boyde, 1968), as well as tissue organization of uterine epithelium during delayed implantation (Psychoyos \& Mandon, 1971) and cervical neoplasia (Jordan \& Williams, 1971). The purpose of this study was to observe the morphology and tissue organization of ciliated and secretory epithelium in the female reproductive tract.

The reproductive tracts of four adult female crab-eating macaque, Macaca fascicularis, and six adult female New Zealand rabbits were dissected $3 \mathrm{hr}$ post coitum, with or without fixation in vivo with $2 \%$ glutaraldehyde (Reinius \& Nilsson, 1969). Tissue specimens were pinned to Dow Corning 780 sealant and fixed for $20 \mathrm{hr}$ in refrigerated $4 \%$ or $6 \%$ cacodylate-buffered glutaraldehyde. The fixative was decanted and replaced with cacodylate-buffered sucrose (Sabatini, Bensch \& Barnett, 1963). After 24 to $30 \mathrm{hr}$ in sucrose, the specimens were washed twice in the buffer solution and post-fixed for $1 \mathrm{hr}$ in buffered $1.2 \%$ osmium tetroxide (Kanagawa, Hafez, Baechler, Pitchford \& Banrhart, 1972). The tissues were rinsed twice with $70 \%$ ethanol and dehydrated in graded concentrations of ethanol to $100 \%$ and then in $100 \%$ propylene oxide (Cleveland \& Schneider, 1968).

The samples were infiltrated for 30 to $90 \mathrm{~min}$ at room temperature with freshly prepared maraglass mixture $(37.5 \mathrm{ml}$ maraglass No. $655 ; 7.5 \mathrm{ml}$ dibutyl phthalate; $1.0 \mathrm{ml}$ BDMA), diluted $1: 1$ with $100 \%$ propylene oxide. After treatment with undiluted maraglass at room temperature for $20 \mathrm{~min}$ and at $60^{\circ} \mathrm{C}$ for $20 \mathrm{~min}$, the samples were allowed to cool to room temperature, and the maraglass on the surfaces was washed off thoroughly with a jet of hot acetone.

Using conductive glue, the samples were fixed to specimen stubs either in flat preparation for scanning of surface topography or perpendicularly for crosssectional topography. For optimal resolution, the samples were rotary shadowed with $300 \AA$ of gold-palladium ( $60 \%$ gold: $40 \%$ palladium; purity of $99.99 \%$ ) from $90^{\circ}$ and $45^{\circ}$ angles in vacuo. A DV-502 high vacuum evaporator (Denton 
Vacuum) was used. A $10^{-4}$ Torr was reached in the outgassed system within $3 \mathrm{~min}$, and a $5 \times 10^{5}$ Torr within $4 \mathrm{~min}$ in the standard 12 in. diam $\times 12$ in. bell jar. Specimens were examined in a Cambridge Stereoscan Mark II Scanning Microscope (220 $\AA$ resolution) using the emission made of an accelerating voltage of $20 \mathrm{kV}$ and at a $40^{\circ}$ angle. The identification of individual cells by scanning electron microscopy was confirmed by light microscopy.

Two cell types were observed in the epithelium of the reproductive tract: ciliated cells and non-ciliated secretory cells (e.g. Pl. 1, Fig. 1). Ciliated cells were covered by kinocilia which overlapped the surface of secretory cells. The non-ciliated cells had a dome-shaped surface and were covered with secretory microvilli (e.g. Pl. 1, Fig. 2) or microridges with junctional complexes between adjacent cells. There were remarkable morphological differences between the tissue organization of the mucosa of the same organ in the two species studied and among different segments of the reproductive organs in the same species. These differences were particularly noted in the abundance of ciliated cells, number of cilia/cell, number and structure of secretory microvilli, the junctional complexes between adjacent secretory cells and the nature of adhering secretory material.

In the oviduct, ciliated cells were very abundant, especially in the fimbriae (Pl. 1, Figs 1 and 3). The percentage of ciliated cells decreased gradually from the ampulla to the isthmus. In the endometrium of both species, ciliated cells were scattered among the secretory cells (Plate 2, Figs 4 to 7). The secretory microvilli of the non-ciliated cells were rounded and shorter than those in the oviduct. The cervical epithelium of the rabbit had many more ciliated cells than that of the monkey, and the ectocervix in the rabbit contained less ciliated cells than the endocervix (Pl. 3, Figs 8 to 11 and Pl. 4, Figs 12 to 15). Secretory granules were observed on the surfaces of microvilli, kinocilia and the heads of spermatozoa (Pl. 2, Fig 7 and Pl. 5, Fig 16). In areas of the rabbit cervical epithelium, spermatozoa were seen to be undergoing phagocytosis by leucocytes (Pl. 5, Figs 17 and 18).

The surface morphology of secretory cells, which varies in different segments of the reproductive tract, may be related to differences in membrane activity. Using histochemical techniques, several varieties of secretory and ciliated cells were noted in the cervical and uterine mucosa of macaques and rabbits (Hafez, El Banna \& Yamashita, 1971; Hafez \& Kanagawa, 1972).

Kinocilia play an important part in the transport of particles and in directing the flow of luminal fluids in the reproductive tract. The directional beat of the cilia propels fluid currents toward the uterus. Although the basic structure of cilia and the variations throughout the biological systems are well documented (Satir, 1965; Brenner, 1969), little is known about the mechanisms of ciliary

\section{EXPLANATION OF PLATE 1}

Scanning electron micrographs of ciliated and secretory cells in the fimbriae of oviduct in the crab-eating macaque, Macaca fascicularis, (Figs 1 and 2) and the rabbit (Fig. 3).

Fig. 1. Ciliated and secretory cells. $\times 180$.

Fig. 2. Secretory cells with abundant microvilli. $\times 5220$.

Fig. 3. Secretory (s) and ciliated (c) cells. $\times 3870$. 

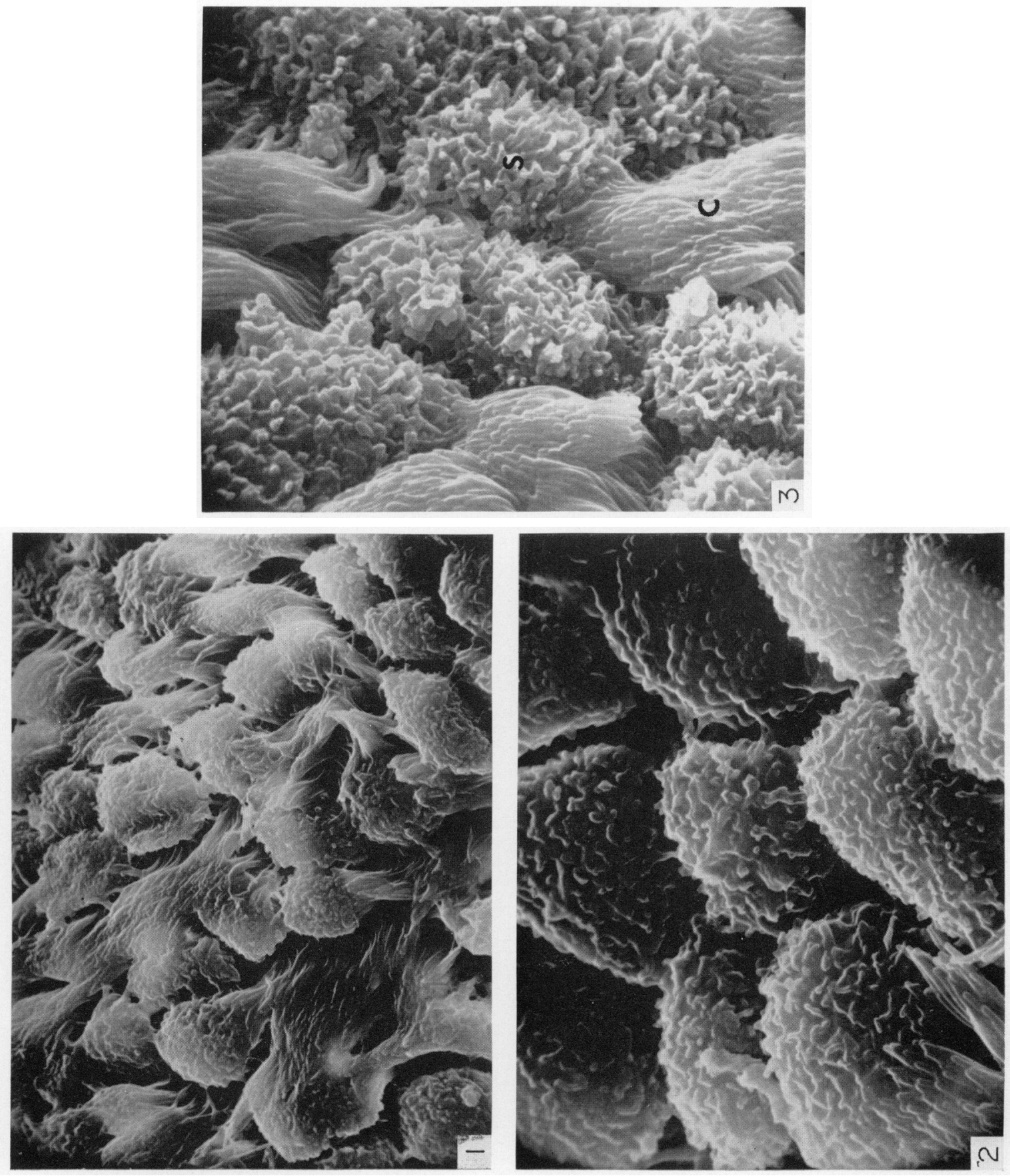

Faris p. 294 

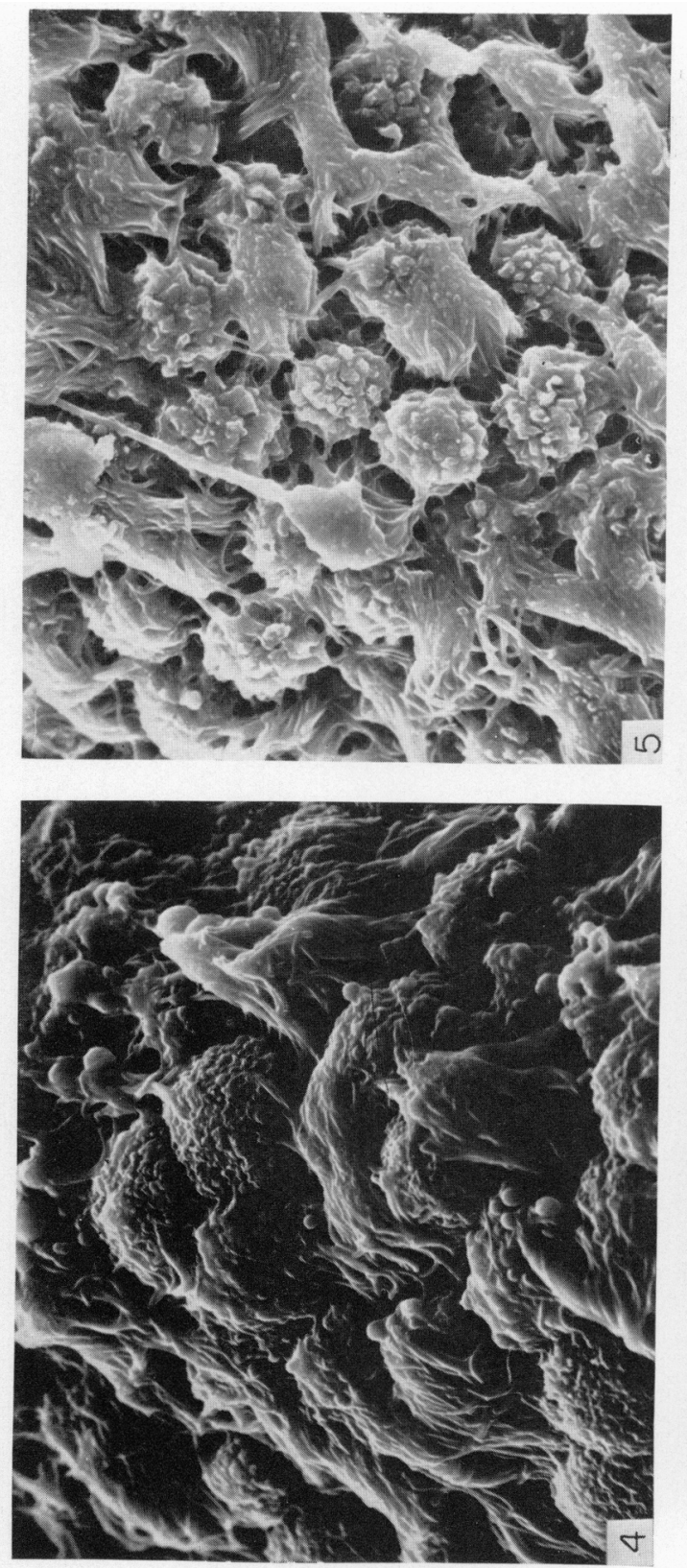
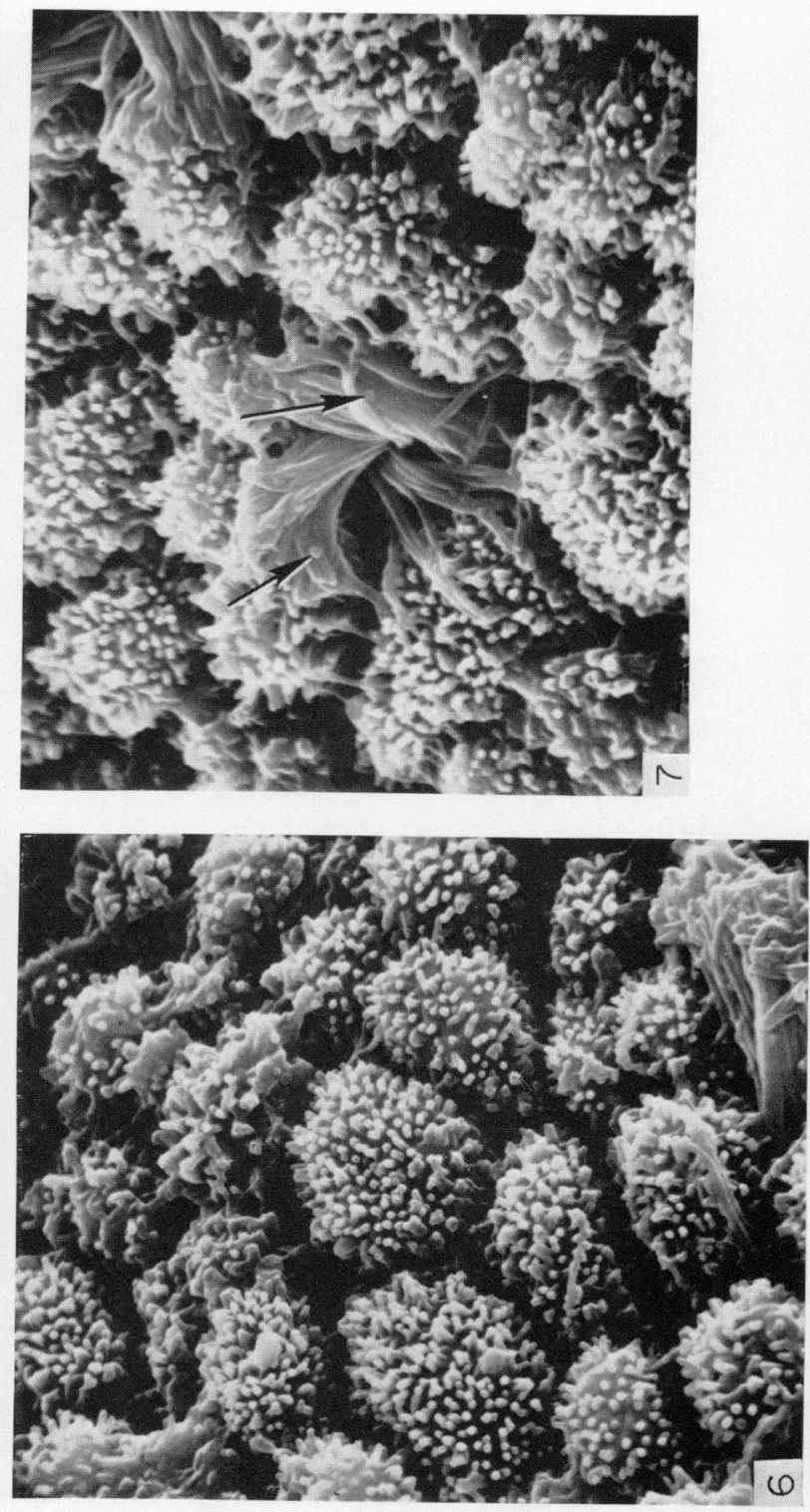
motion. It is suggested that the kinocilia of the cervix, which beat toward the vagina, sweep away abnormal spermatozoa, and facilitate the liberation of micelles of cervical mucus from the adjacent secretory cells.

This investigation was supported in part by The Ford Foundation Grant 710-0287.

\section{REFERENCES}

BARBe, V. C. \& Boyde, A. (1968) Scanning electron microscopical studies of cilia. Z. Zellforsch, mikrosk. Anat. 84, 269.

BRENNER, R. M. (1969) The biology of oviductal cilia. In: The Mammalian Oviduct, p. 203. Eds. E. S. E. Hafez and R. J. Blandau. Chicago University Press.

Gleveland, P. H. \& Schnemer, C. W. (1968) A simple method of preserving ocular tissue for scanning electron microscopy. Vision Res. 9, 1401.

Dotт, H. M. (1969) Preliminary examination of bull, ram and rabbit spermatozoa with the stereoscan electron microscope. F. Reprod. Fert. 18, 133.

Fujrta, T., Mryoshi, M. \& Tokunaga, J. (1970) Scanning and transmission electron microscopy of human ejaculate spermatozoa with special reference to their abnormal forms. Z. Zellforsch. mikrosk. Anat. 105, 483.

Gould, K. G., Zaneveld, L. J. D., Humphreys, W. J. \& Williams, W. L. (1971) Rabbit gametes: scanning electron microscopy at early stages of fertilization. J. reprod. Med. 6, 18.

Hapez, E. S. E., EL BanNa, A. A., \& Yamashita, Y. (1971) Histochemical characteristics of cervical epithelia in rabbits and cattle. Acta histochem. 39, 195.

HafEz, E. S. E. \& Kanagawa, H. (1972) Ciliated epithelium in the uteri cervix of the macaque and rabbit. 7. Reprod. Fert. 28, 91.

JoRdan, J. A. \& WrLliams, A. E. (1971) Scanning electron microscopy in the study of cervical neoplasia. 7. Obstet. Gynaec. Br. Commonw. 78, 940.

Kanagawa, H., Hafez, E. S. E., Bagchler, C. A., Pitchyord, W. G. \& Barnhart, M. I. (1972) Improved methodology for scanning electron microscopy of the female reproductive tract. Int. $\mathcal{F}$. Fert. 17, (in press).

Luse, S. A. (1970) Preparation of biologic specimens for scanning electron microscopy. Proc. 3rd Ann. Cambridge Stereoscan Collog. 3, 149.

Psychoyos, A., \& Mandon, P. (1971) Scanning electron microscopy of the surface of the rat uterine epithelium during delayed implantation. F. Reprod. Fert. 26, 137.

Reinius, S. \& Nisson, O. (1969) Light and electron microscopic structure of the oviduct. In: The Mammalian Oviduct, p. 57. Eds. E. S. E. Hafez and R. J. Blandau. Chicago University Press.

Sabatini, D. D., Bensch, K. G. \& Barnett, R. J. (1963) Cytochemistry and electron microscopy: the preservation of cellular ultrastructure and enzymatic activity by aldehyde fixation. 7 . Cell Biol. 17, 19.

SATIR, P. (1965) Structure and function in cilia and fagella: protoplasmatologia. In: Handbuch der Protoplasmaforchung, Vol. 3/E, pp. 1-52. Springer, New York.

Zanevel.d, L. J. D., Gould, K. G., Humphreys, W. J. \& Williams, W. L. (1971) Scanning electron microscopy of mammalian spermatozoa. F. reprod. Med. 6, 13.

\section{EXPLANATION OF PLATE 2}

Scanning electron micrographs in the rabbit.

Fig. 4. Secretory and ciliated cells in the isthmus of oviduct. $\times 1600$.

Frg. 5. Secretory and ciliated cells in the ampullary-isthmic junction, with one spermatozoon. $\times 1600$.

FIG. 6. 'Chrysanthemum-like' secretory cells in the uterus, with abundant secretory microvilli. $\times 4000$.

Fig. 7. Ciliated cell with prominent kinocilia among secretory cell in the uterus. Note secretory granules (arrows). $\times 4000$. 


\section{EXPLANATION TO PLATES 3-5}

\section{PLATE 3}

Scanning electron micrograph of the mid-cervix in the female macaque.

Fig. 8. Note the presence of cervical crypts (arrows). Note mucus covering the epithelium at 9 to 10 o'clock. $\times 207$.

FIG. 9. Secretory cells with irregularly shaped secretory microvilli. $\times 900$.

Fig. 10. Secretory cells with junctional complexes. $\times 1800$.

Frg. 11. One ciliated cell among secretory cells. $\times 5220$.

\section{PLATE 4}

Scanning electron micrographs of the cervical epithelium in the rabbit.

Frg. 12. Note the complexity of cervical crypts. $\times 18$.

Fig. 13. Secretory and ciliated cells. $\times 1800$.

Fig. 14. Giliated cells and one spermatozoon. $\times 4500$.

FIG. 15. Secretory cells with junctions (arrow) between some of the adjacent microvilli. $\times 4500$.

\section{PLATE 5}

Scanning electron micrographs of spermatozoa on the cervical epithelium in the rabbit. Fig. 16. Note secretory granules on sperm head. $\times 9000$.

Fig. 17. Phagocytosis of spermatozoa by leucocytes. $\times 450$.

Fig. 18. Phagocytosis of spermatozoa by leucocytes. Some spermatozoa (a) are located on the surface of leucocytes, whereas others (b) are engulfed by the leucocytes. $\times 1800$. 

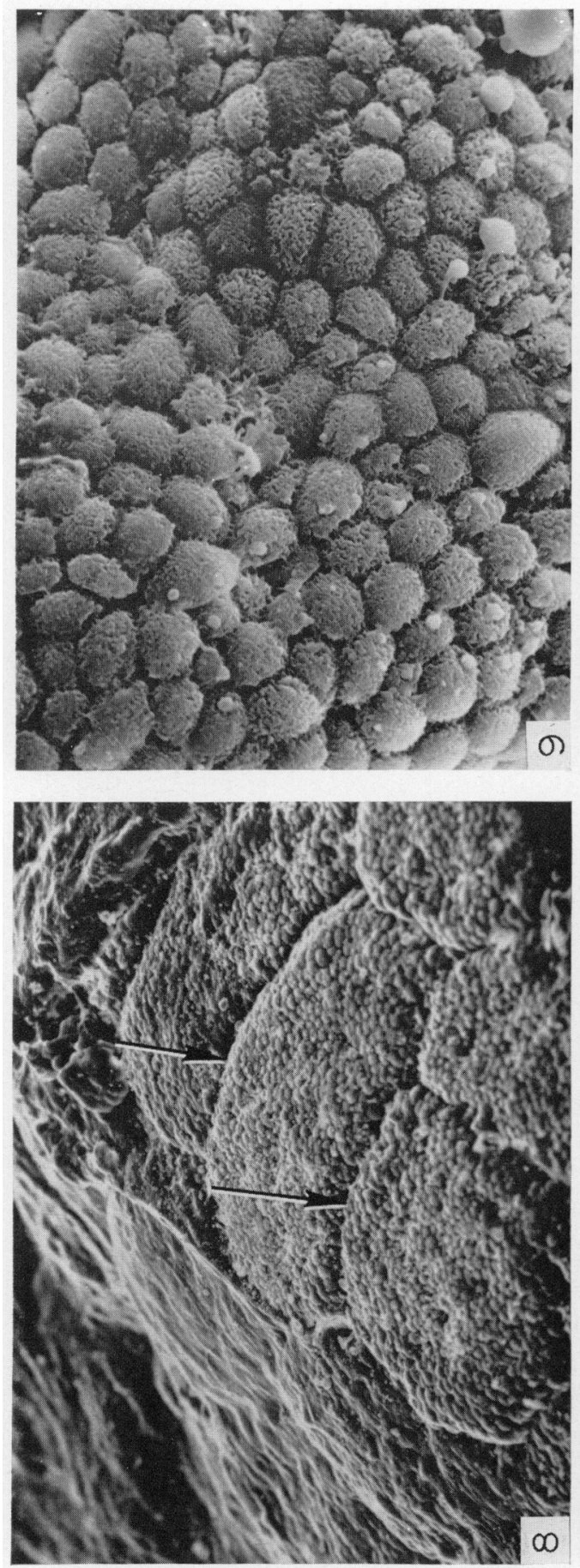
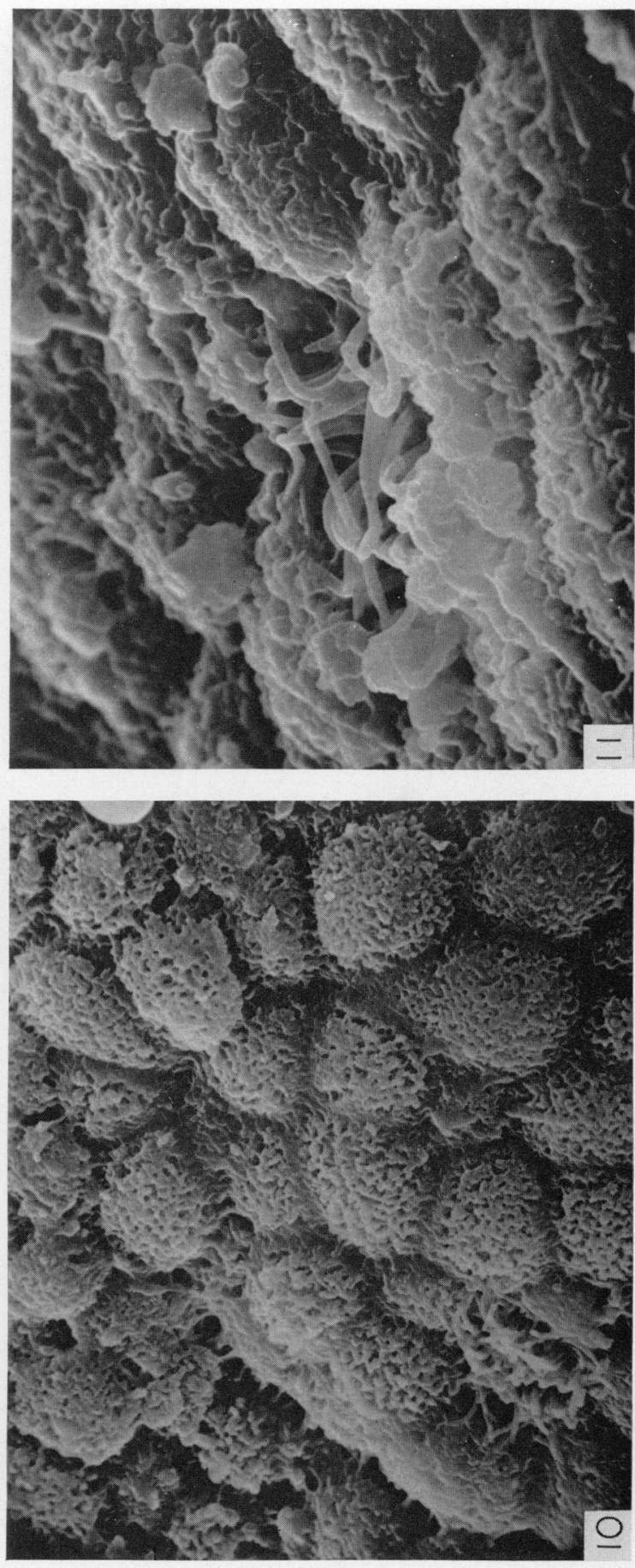

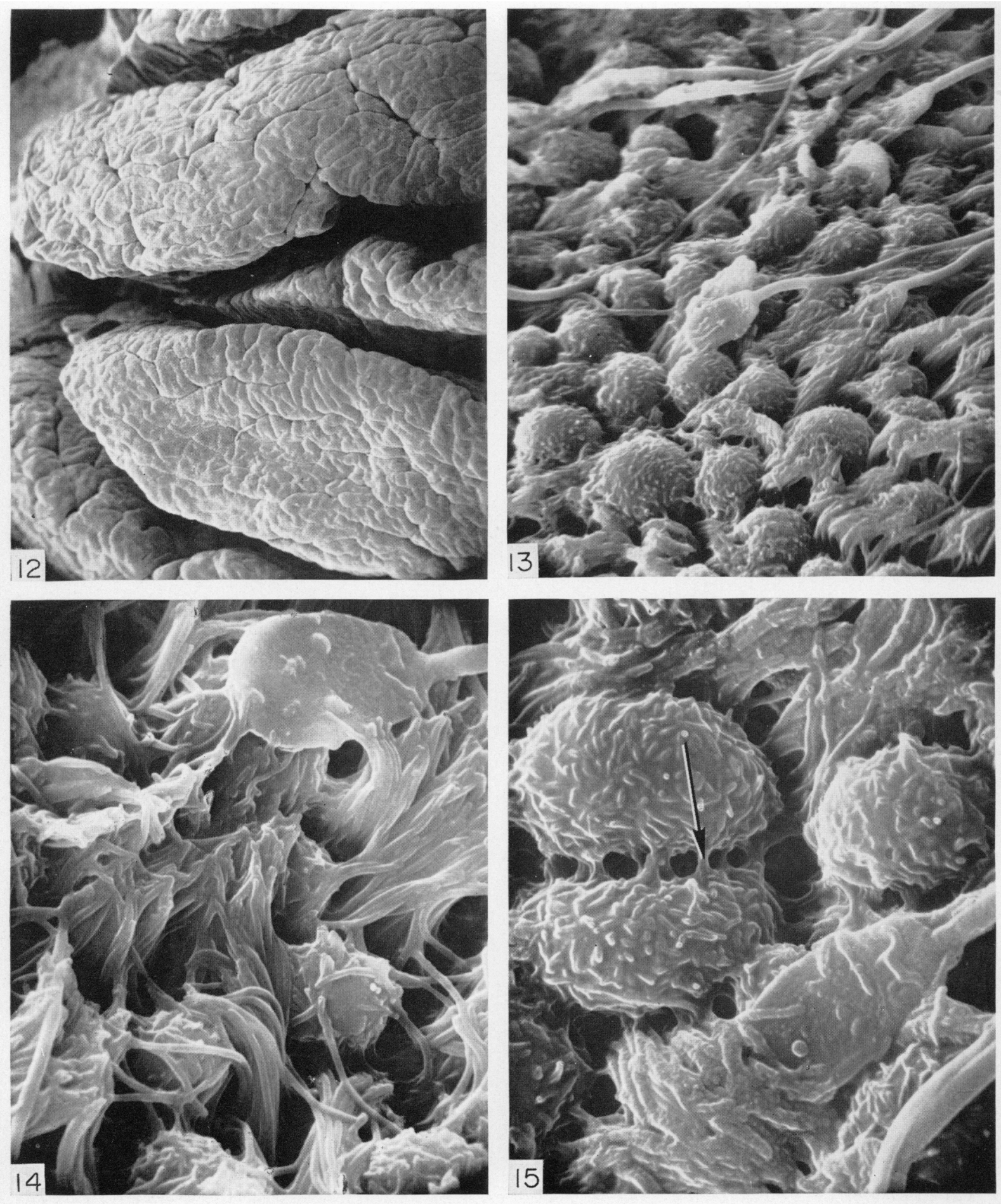

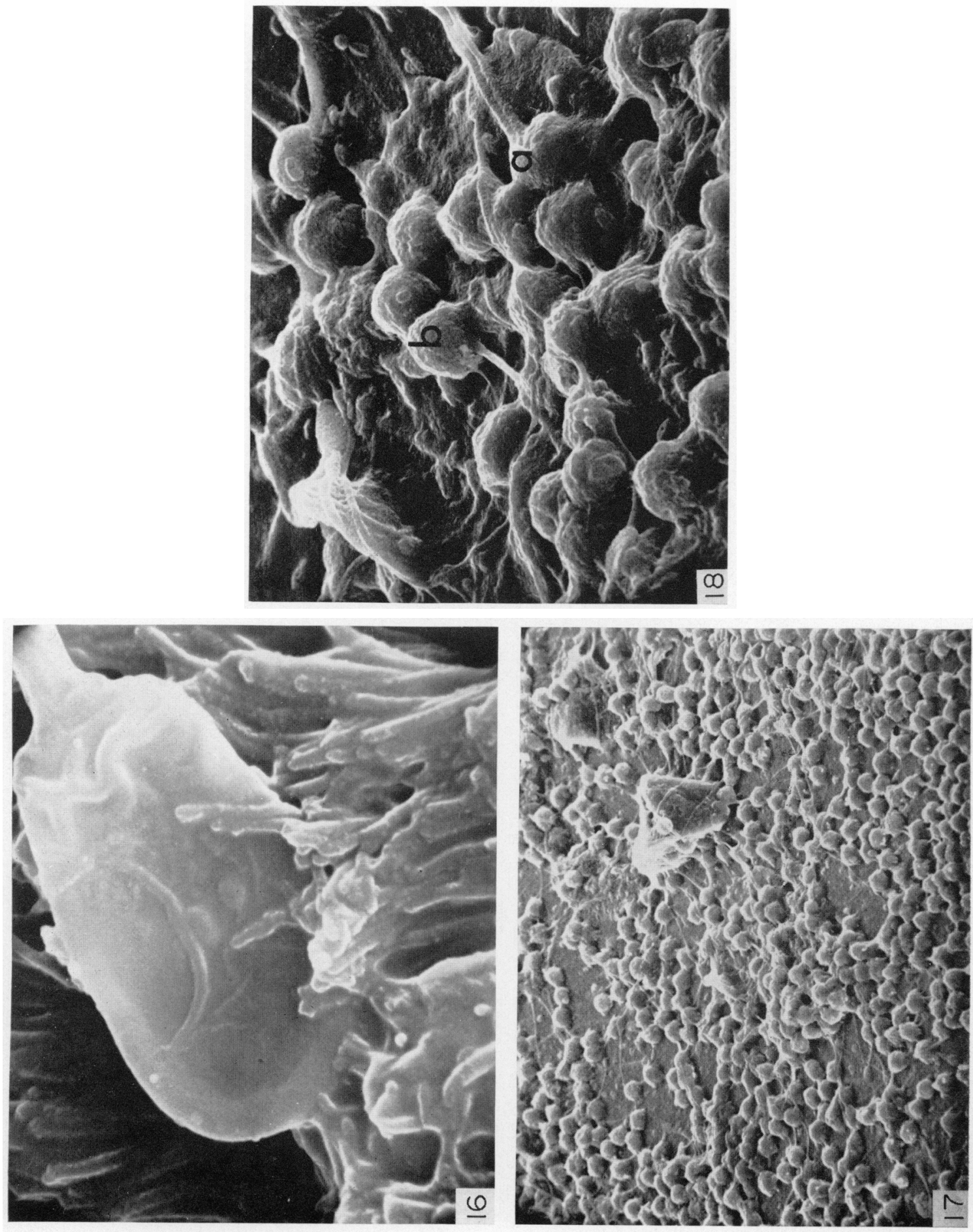